\title{
OPTIMALISASI PEMBELAJARAN TEMATIK \\ BERBASIS EXPERIENTIAL LEARNING \\ UNTUK MADRASAH IBTIDAIYAH
}

Oleh:

Atikah Syamsi, M.Pd.I

\begin{abstract}
Among alternative learning can be used to answer one of the problems in education related to the learning experience is to use the model of experiential learning that is almost similar to a scientific approach in thematic learning. Where thematic learning is more emphasis on the application of the concept of learning by doing something (learning by doing ). Therefore, teachers need to package or design a learning experience that would affect the significance of student learning. Learning experiences that demonstrate this relationship conceptual elements make the learning process more effective. Conceptual connection between subjects studied and will form the scheme, so that students will acquire knowledge of the unity and unanimity. Additionally, with the implementation of thematic learning in elementary school will help students, because according to the stage of development of students who still see everything as a whole (holistic).

This research is a field (field research) is research by going directly to research places to observe and engage directly with the object of research. Type of research is qualitative research with inductive logic thinking. Sources of data in the study is the subject of where the data was obtained, the determination of the data is obtained by applying the population, meaning that the entire party in the role of research as a research target. Given in this study used a qualitative approach, the data analysis starts from the ground by using descriptive analytic method that is compiled by describing, interpreting data and analyzing all the things that are the focus of this research
\end{abstract}

Keywords : Experiential Learning, Thematic Learning, Elementary School 


\section{OPTIMALISASI PEMBELAJARAN TEMATIK \\ BERBASIS EXPERIENTIAL LEARNING \\ UNTUK MADRASAH IBTIDAIYAH}

\section{A. Latar Belakang Masalah}

Terdapat kecenderungan dalam pendidikan dewasa ini untuk kembali pada pemikiran bahwa anak akan belajar lebih baik jika lingkungan diciptakan alamiah. Belajar akan lebih bermakna jika anak mengalami apa yang dipelajarinya, bukan mengetahuinya. Pembelajaran yang berorientasi pada penguasaan materi terbukti berhasil dalam kompetisi mengingat jangka pendek tetapi gagal dalam membekali anak memecahkan persoalan dalam kehidupan jangka panjang.Belajar merupakan istilah kunci yang paling vital dalam usaha pendidikan, sehingga ada ungkapan yang menyatakan bahwa tanpa belajar sesungguhnya tidak pernah ada pendidikan. Sebagai suatu proses, belajar hampir selalu mendapat tempat yang luas dalam berbagai disiplin ilmu yang berkaitan dengan pendidikan. Disini letak pentingnya manusia sebagai makhluk yang berpikir untuk terus belajar, baik itu belajar secara kelembagaan formal maupun belajar dari pengalaman yang pernah dan akan dialami.

Maksud dan tujuan belajar tidak hanya berorientasi pada penguasaan materi dengan menghapal fakta-fakta yang tersaji dalam bentuk informasi atau materi pelajaran. Lebih jauh daripada itu, orientasi sesungguhnya dari proses belajar adalah memberikan pengalaman untuk jangka panjang. Dengan konsep ini, hasil pembelajaran diharapkan lebih bermakna bagi siswa. Proses pembelajaran berlangsung secara alamiah dalam bentuk kegiatan siswa bekerja dan mengalami, bukan tansfer pengetahuan dari guru ke siswa. Proses pembelajaran seharusnya dapat menciptakan suatu proses belajar yang dapat mengeksplorasi wawasan pengetahuan siswa dan dapat mengembangkan makna sehingga akan memberikan kesan yang mendalam terhadap apa yang telah dipelajarinya ( Budiningsih, 2002).

Peningkatan kualitas pendidikan anak di Indonesia salah satunya ditandai dengan indikasi maraknya tempat penitipan anak dan sekolah ramah anak. Paradigma masa silam yang menganggap pendidikan anak lebih menekankan pada membaca dan menulis kini telah beralih kepada pendidikan anak yang lebih menonjolkan kepada penanaman konsep yang dibalut dengan permainan dan pengembangan pengalaman anak secara mandiri, namun penerapan ini hanya dilakukan oleh beberapa lembaga 
pendidikan saja. Secara global fenomena ini menunjukkan peningkatan kesadaran dan pemahaman orang tua terhadap korelasi permainan dan pembelajaran. (Uno, 2006)

Diantara alternatif pembelajaran yang dapat digunakan untuk menjawab permasalahan diatas salah satunya adalah dengan menggunakan model experiential learning yang hampir serupa dengan pendekatan scientific dalam pembelajaran tematik. Dimana pembelajaran tematik ini lebih menekankan pada penerapan konsep belajar sambil melakukan sesuatu (learning by doing). Oleh karena itu, guru perlu mengemas atau merancang pengalaman belajar yang akan mempengaruhi kebermaknaan belajar siswa. Pengalaman belajar yang menunjukkan kaitan unsurunsur konseptual menjadikan proses pembelajaran lebih efektif. Kaitan konseptual antar mata pelajaran yang dipelajari akan membentuk skema, sehingga siswa akan memperoleh keutuhan dan kebulatan pengetahuan. Selain itu,dengan penerapan pembelajaran tematik di sekolah dasar akan sangat membantu siswa,karena sesuai dengan tahap perkembangannya siswa yang masih melihat segala sesuatu sebagai satu keutuhan (holistik). (Lie, 2004)

Jika ditelaah kembali tentang tujuan pendidikan dasar, antara lain agar anak dapat mengenal alam sekitar. Alam sekitar ini termasuk "lingkungan". Jadi segala sesuatu di sekitar anak itu merupakan objek untuk diajarkan kepada anak, atau lingkungan merupakan sasaran belajar bagi anak pada jenjang dasar, oleh karenanya menjadi upaya yang seharusnya dapat dikerjakan bersama-sama antara pengajar dan seluruh stakeholdernya untuk bisa melakukan optimasi terhadap pendekatan scientific berbasis experiential learning yang mampu memfasilitasi kebutuhan anak terhadap pengalaman kognisi, fisik-motorik serta pengenalan anak terhadap lingkungan sekitarnya.

\section{B. Kajian Teori}

Adapun beberapa kajian dan teori yang melandasi munculnya latar belakang diatas ialah antara lain mengenai konsepsi baru yang diharapkan nantinya dapat melahirkan model pembelajaran yang berdasar pada kebutuhan, dan bukan semata pendidikan yang dilakukan karena ingin menyelesaikan tugas selama satu semester saja.

1. Konsep Pembelajaran Tematik Integratif

Pembelajaran tematik berasal dari kata integrated teaching and learning atau integrated curriculum approach yang konsepnya telah lama dikemukakan 
oleh John Dewey sebagai usaha untuk mengintegrasikan perkembangan dan pertumbuhan siswa dan kemampuan pengetahuannya.

Jacobs (1989) memandang pembelajaran tematik sebagai suatu pendekatan kurikulum interdisipliner (integrated curriculum approach). Pembelajaran tematik merupakan suatu pendekatan dalam pembelajaran sebagai suatu proses untuk mengaitkan dan memadukan materi ajar dalam suatu mata pelajaran atau antarmata pelajarandengan semua aspek perkembangan anak, serta kebutuhan dan tuntutanlingkungan social keluarga.

Pembelajaran tematik lebih menekankan pada keterlibatan siswa dalam proses belajar secara aktif, sehingga siswa dapat memperoleh pengalaman langsung dan terlatih untuk dapat menemukan sendiri berbagai pengetahuan yang dipelajari. Melalui pengalaman langsung siswa akan memahami konsep-konsep yang mereka pelajari dan menghubungkannya dengan konsep lain yang telah dipahaminya. Teori pembelajaran ini dimotori para tokoh Psikologi Gestalt, termasuk Piaget yang menekankan bahwa pembelajaran haruslah bermakna dan berorientasi pada kebutuhan dan perkembangan anak. Pembelajaran tematik lebih menekankan pada penerapan konsep belajar sambil melakukan sesuatu (learning by doing), maka guru perlu mengemas atau merancang pengalaman belajar yang mempengaruhi kebermaknaan belajar siswa. (Baharuddin, 2007) Pengalaman belajar yang menunjukkan kaitan unsur-unsur konseptual menjadikan proses pembelajaran lebih efektif. Kaitan konseptual antar mata pelajaran yang dipelajari akan membentuk skema, sehingga siswa akan memperoleh keutuhan dan kebulatan pengetahuan. Penerapan pembelajaran tematik di sekolah juga sangat membantu siswa, karena sesuai dengan tahap perkembangan siswa yang masih melihat segala sesuatu sebagai satu keutuhan (holistic)

Secara ringkas, Sugianto mengidentifikasi karakateristik pembelajaran tematik sebagai berikut ;

a. Holistik

Suatu gejala atau fenomena yang menjadi pusat perhatian dalam pembelajaran tematik diamati dan dikaji dari beberapa bidang kajian sekaligus, tidak terkotak-kotak. Pembelajaran tematik memungkinkan siswa untuk memahami suatu fenomena dari segala sisi, sehingga akan membuat 
siswa menjadi lebih arif dan bijak dalam menyikapi atau menghadapi kejadian yang ada di depan mereka.

b. Bermakna

Pengkajian suatu fenomena dengan banyak membentuk jalinan antar konsep-konsep yang berhubungan menghasilkan skemata. Yang akan berdampak pada kebermaknaan dari materi yang dipelajari. Rujukan yang nyata dari segala konsep yang diperoleh, dan kebermaknaan yang dipelajari. Selanjutnya akan mengakibatkan pembelajaran fungsional. Siswa mampu menerapkan perolehan untuk memecahkan masalah-masalah yang muncul di dalam kehidupannya.

c. Otentik

Pembelajaran tematik memungkinkan siswa memahami secara langsung prinsip dan konsep melalui kegiatan belajar secara langsung. Dengan memahami dari hasil belajarnya sendiri, bukan pemberitahuan guru. Informasi dan pengetahuan yang diperoleh siswa melalui kegiatan eksperimen. Guru lebih banyak bersifat sebagai fasilitator dan katalisator, sedang siswa bertindak sebagai aktor pencari informasi dan pengetahuan.

d. Aktif

Pembelajaran tematik menekankan keaktifan siswa dalam pembelajaran baik secara fisik, mental, intelektual, maupun emosional guna mencapai hasil belajar yang optimal dengan mempertimbangkan hasrat, minat, dan kemampuan siswa, sehingga mereka termotivasi untuk terus belajar. Pembelajaran tematik bukan semata-mata merancang aktivitas-aktivitas dari masing-masing mata pelajaran yang saling terkait.

Sementara itu Wolfinger mengemukakan dua istilah yang secara teoretis memiliki hubungan yang sangat erat, yaitu integrated curriculum (kurikulum tematik) dan integrated learning (pembelajaran tematik). Kurikulum tematik adalah kurikulum yang menggabungkan sejumlah disiplin ilmu melalui pemaduan isi, keterampilan, dan sikap.

Rasional pemaduan itu antara lain disebabkan oleh beberapa hal berikut:

1. Kebanyakan masalah dan pengalaman (termasuk pengalaman belajar) bersifat interdisipliner, sehingga untuk memahami, mempelajari dan memecahkannya diperlukan "multi-skill”. 
2. Adanya tuntutan interaksi kolaboratif yang tinggi dalam memecahkan berbagai masalah.

3. Memudahkan anak membuat hubungan antar skemata dan transfer pemahaman antar konteks.

4. Demi efisiensi; dan

5. Adanya tuntutan keterlibatan anak yang tinggi dalam proses pembelajaran.

Sejalan dengan hal tersebut di atas, pembelajaran tematik banyak dipengaruhi oleh eksplorasi topik yang ada di dalam kurikulum sehingga anak dapat belajar menghubungkan proses dan isi pembelajaran secara lintas disiplin dalam waktu yang bersamaan.

Sebelum memasuki bangku sekolah, anak terbiasa memandang dan mempelajari segala peristiwa yang terjadi di sekitarnya atau yang dialaminya sebagai suatu kesatuan yang utuh (holistik), mereka tidak melihat semua itu secara parsial (terpisah-pisah). Sayangnya, ketika memasuki situasi belajar secara formal di bangku sekolah, mereka disuguhi oleh berbagai materi ilmu atau mata pelajaran yang terpisah satu sama lain sehingga mereka terkadang mengalami kesulitan untuk memahami fenomena yang terjadi di lingkungan masyarakat dan alam sekitarnya. Penyelenggaraan pendidikan dengan menekankan pada pembelajaran yang memisahkan penyajian antar satu mata pelajaran dengan mata pelajaran lainnya akan mengakibatkan permasalahan yang cukup serius terutama bagi peserta didik usia SD/MI.

Oleh sebab itu perlu adanya perubahan dan peningkatkan efisiensi penyelenggaraan pendidikan dan formalisasi sistem pendidikan dengan menekankan pada pembelajaran yang memisahkan penyajian per mata pelajaran yang akan membuat masalah yang serius terutama bagi usia muda siswa SD/MI, pembelajaran di jenjang SD/MI terutama untuk kelas-kelas awal harus memperhatikan karakteristik siswa yang akan menghayati pengalaman belajar sebagai suatu kesatuan yang utuh (holistik). (Silberman, 2001). Pembelajaran yang memisahkan penyajian per mata pelajaran, secara tegas hanya akan membuahkan kesulitan bagi siswa karena pemisahan seperti itu hanya akan memberikan pengalaman belajar yang bersifat artifisial.

Dengan demikian, jelas bahwa pengemasan pembelajaran yang dirancang bagi para siswa akan berpengaruh terhadap kebermaknaan 
pengalaman belajar mereka. Pengalaman belajar yang menunjukkan kaitan unsur-unsur konseptual baik intra maupun antar mata pelajaran akan memberi peluang bagi terjadinya pembelajaran yang lebih bermakna dan efektif. Pembelajaran tematik sebagai suatu konsep dapat dikatakan sebagai pendekatan pembelajaran yang melibatkan beberapa mata pelajaran untuk memberikan pengalaman belajar yang bermakna kepada siswa. Pembelajaran tematik diyakini sebagai pendekatan pembelajaran yang berorientasi pada praktik pembelajaran yang sesuai dengan kebutuhan anak. Melalui implementasi pendekatan tematik, khususnya di SD/MI, kualitas proses dan hasil pembelajaran diharapkan akan semakin berkualitas.

\section{Konsepsi Experiential learning}

Gagasan pendidikan berbasis pengalaman (experiential education) atau yang disebut "learning by doing" memiliki sejarah panjang. Awalnya, para guru outdoor menyebut experiential education sebagai gaya belajar di luar ruangan. Senada dengan itu, program pendidikan petualangan, yang berlangsung di luar ruangan (outdoor), memanfaatkan pengalaman di dunia nyata untuk mencapai tujuan belajarnya. Pemikiran mengenai pendidikan berbasis pengalaman semakin berkembang dengan munculnya karya John Dewey (1938) dan David Kolb (1984) yang mengungkapkan pentingnya pembelajaran melalui pengalaman sebagai landasan dalam menetapkan pendidikan formal.

Metode Experiential Learning adalah suatu metode proses belajar mengajar yang mengaktifkan siswa untuk membangun pengetahuan dan keterampilan serta nilai-nilai juga sikap melalui pengalamannya secara langsung. Oleh karena itu, metode ini akan bermakna tatkala siswa ikut berperan serta dalam melakukan kegiatan. Setelah itu, mereka memandang kritis kegiatan tersebut. Kemudian, mereka mendapatkan pemahaman serta menuangkannya dalam bentuk lisan atau tulisan sesuai dengan tujuan pembelajaran. Dalam hal ini, Experiential Learning menggunakan pengalaman sebagai katalisator untuk menolong pembelajar mengembangkan kapasitas dan kemampuannya dalam proses pembelajaran.

Experiential learning merupakan sebuah model holistic dari proses pembelajaran di mana manusia belajar, tumbuh dan berkembang. Penyebutan istilah experiential learning dilakukan untuk menekankan bahwa experience 
(pengalaman) berperan penting dalam proses pembelajaran dan membedakannya dari teori pembelajaran lainnya seperti teori pembelajaran kognitif ataupun behaviorisme (Kolb, 1984).

Experiential learning memiliki makna yang berbeda-beda, namun mengacu kepada satu pemikiran. (Achsin, 1984). Menurut Association for Experiential Education (AEE), experiential learning merupakan falsafah dan metodologi dimana pendidik terlibat langsung dalam memotivasi peserta didik dan refleksi difokuskan untuk meningkatkan pengetahuan, mengembangkan keterampilan. Experiential learning mendorong siswa dalam aktivitasnya untuk berpikir lebih banyak, mengeksplor, bertanya, membuat keputusan, dan menerapkan apa yang telah mereka pelajari.

Experiential learning adalah suatu pendekatan yang dipusatkan pada siswa yang dimulai dengan landasan pemikiran bahwa orang-orang belajar terbaik itu dari pengalaman. Dan untuk pengalaman belajar yang akan benar-benar efektif, harus menggunakan seluruh roda belajar, dari pengaturan tujuan, melakukan observasi dan eksperimen, memeriksa ulang, dan perencanaan tindakan. Apabila proses ini telah dilalui memungkinkan siswa untuk belajar keterampilan baru, sikap baru atau bahkan cara berpikir baru.

Experiential learning itu sendiri berisi 3 aspek yaitu: Pengetahuan (konsep, fakta, informasi), Aktivitas (penerapan dalam kegiatan) dan Refleksi (analisis dampak kegiatan terhadap perkembangan individu).

Berdasarkan pendapat di atas dapat dipahami bahwa penerapan model experiential learning dapat membantu siswa dalam membangun pengetahuannya sendiri (Depdiknas, 2002). Seperti halnya model pembelajaran lainnya, dalam menerapakan model experiental learning guru harus memperbaiki prosedur agar pembelajarannya berjalan dengan baik.

3. Pembelajaran tematik berbasis Experiential Learning

Pembelajaran tematik berbasis Experiential Learning sebagai suatu konsep merupakan pendekatan pembelajaran yang melibatkan beberapa mata pelajaran untuk memberikan pengalaman belajar yang bermakna bagi anak. Pembelajaran tematik diyakini sebagai pendekatan yang berorientasi pada praktik pembelajaran yang sesuai dengan kebutuhan anak. Pembelajaran tematik secara efektif akan membantu menciptakan kesempatan yang luas bagi siswa untuk melihat dan 
membangun konsep-konsep yang saling berkaitan. Dengan demikian, pembelajaran akan memberikan kesempatan kepada siswa untuk memahami masalah yang kompleks yang ada di lingkungan sekitarnya dengan pandangan yang utuh. Dengan pembelajaran tematik ini siswa diharapkan memiliki kemampuan untuk mengidentifikasi, mengumpulkan, menilai dan menggunakan informasi yang adadi sekitarnya secara bermakna. Hal itu dapat diperoleh tidak saja melalui pemberian pengetahuan baru kepada siswa melainkan juga melalui kesempatan memantapkan dan menerapkannya dalam berbagai situasi baru yang semakin beragam. Dengan demikian, keterpaduan dalam pembelajaran tematik ini dapat dilihat dari aspek proses, aspek kurikulum, dan aspek belajar mengajar. (Cahyani, 2002)

Sebagaimana dikemukakan di atas, siswa SD/MI pada umumnya melihat segala sesuatu sebagai suatu keutuhan (holistik), perkembangan fisiknya tidak dapat dipisahkan dari perkembangan mental, sosial, dan emosionalnya sehingga pembelajaran tematik hanya diajarkan pada jenjang SD/MI kelas rendah, yaitu kelas 1 sampai kelas 3 .

\section{Metodologi Penelitian}

Penelitian ini merupakan penelitian lapangan (field research) yaitu penelitian dengan cara terjun langsung ke tempat penelitian untuk mengamati dan terlibat secara langsung dengan objek penelitiannya. (Subagyo, 1991) Jenis penelitiannya ialah penelitian kualitatif dengan logika berpikir induktif, dimana penelitian ini memiliki karakteristik bahwa datanya dinyatakan dalam keadaan sewajarnya atau sebagaimana adanya dengan tidak mengubah dalam bentuk simbol ataupun bilangan karena metode penelitian ini memang tidak menggunakan data statistik. (Kountur, 2004) Selain itu dari segi perspektifnya juga penelitian kualitatif lebih menggunakan perspektif emic yang dalam pengumpulan datanya diungkapkan apa adanya, sehingga data yang diperoleh penulis diungkapkan sesuai dengan hasil yang diperoleh di lapangan tanpa ada interpretasi dalam bentuk bilangan. (Usman dkk, 1996)

1. Penentuan Objek dan Subjek Penelitian

Sumber data dalam penelitian adalah subjek dari mana data tersebut diperoleh, penentuan data ini diperoleh dengan cara menerapkan populasi, maksudnya keseluruhan pihak yang ada dalam penelitian berperan sebagai sasaran penelitian. (Arikunto, 1998). Namun dalam penelitian yang memiliki jumlah 
populasi yang besar, tidaklah mungkin untuk mengambil seluruh populasi melainkan diambil beberapa representatif dari populasi tersebut atau yang biasa disebut dengan sampel. Pemilihan sampel atau sampling dalam penelitian kualitatif dimaksudkan untuk menjaring sebanyak mungkin informasi dari berbagai macam sumber dengan tujuan untuk merinci kekhususan yang ada ke dalam laporan, oleh karena itu dalam penelitian kualitatif tidak ada sampel acak melainkan sampel bertujuan (purposive sample). (Moleong, 2002)

\section{Teknik Pengumpulan Data}

Untuk memperoleh data dalam penelitian ini, penulis menggunakan beberapa metode dalam pengumpulan datanya, supaya memperoleh data yang benar-benar valid maka diperlukan berbagai metode bukan hanya satu saja sebab masing-masing metode mempunyai kelebihan dan kelemahan sehingga satu sama lain saling melengkapi. Metode tersebut antara lain :

a. Observasi

Metode observasi diartikan sebagai pengalaman dan pencatatan secara sistemik terhadap gejala yang tampak pada objek penelitian di tempat kejadian atau berlangsungnya peristiwa, sehingga observer berada satu lokasi bersama objek yang diselidiki yang dikenal dengan istilah observasi partisipan atau pengamatan langsung. (Daryono, 1998)

b. Wawancara Mendalam

Wawancara atau yang sering disebut juga dengan interview ialah dialog yang dilakukan oleh peneliti kepada pihak-pihak yang terkait untuk memperoleh informasi yang dibutuhkan. Interview yang digunakan dalam metode ini adalah interview semi struktur, sehingga dalam pelaksanaannya tetap menggunakan metode terpimpin dimana peneliti terlebih dulu mempersiapkan kuesioner yang akan diajukan kepada informan (interview guide), tetapi penyampaian pertanyaannya bisa secara bebas. (Abdurrahman, 2000)

c. Metode Dokumentasi

Metode ini dimaksudkan untuk mencari data mengenai hal-hal atau variabel yang berupa catatan, transkip, buku, surat kabar, majalah, notula rapat, brosur, agenda, foto, rekaman dan lain sebagainya yang dapat menunjang penelitian. 
3. Metode Analisis Data

Mengingat dalam penelitian ini menggunakan pendekatan kualitatif, maka analisis data dimulai dari lapangan dengan menggunakan metode deskriptif analitik yaitu menyusun dengan cara mendeskripsikan, menafsirkan data dan menganalisa semua hal yang menjadi fokus dalam penelitian ini. (Muhadjir, 1998)

Data yang terkumpul dari berbagai sumber disajikan apa adanya kemudian dianalisis dengan menggunakan teknik interpretasi. Penyusunan teori dicapai dengan strategi induktif-empiris, yaitu berangkat dari rincian hal yang spesifik berdasarkan pengalaman nyata baik itu ucapan atau perilaku subjek penelitian maupun situasi lapangan yang ada untuk kemudian dirumuskan menjadi model ataupun konsep yang bersifat umum dengan tujuan untuk menemukan kategori, dimensi-dimensi dan hubungan antar hal yang penting.

\section{Hasil dan Pembahasan}

\section{Experiential learning Sebagai Model Pembelajaran Alternatif}

Experiential Learning merupakan salah satu model pembelajaran yang diterapkan kepada siswa agar siswa tidak lagi menghabiskan waktunya hanya untuk menghafal apa-apa yang telah diketahuinya, dengan diterapkannya Experiential Learning ini diharapkan dapat membantu siswa untuk memahami makna dari materi ajar dengan mengaitkannya terhadap konteks kehidupan mereka sehari-hari. Model pembelajaran ini siswa dituntut dapat memperoleh kesimpulan sendiri tentang apa yang telah dipelajarinya, dan sekali lagi siswa bukan belajar untuk menghafalkan akan tetapi siswa belajar melalui pengalaman.

Penulis mempunyai contoh yang mudah-mudahan dapat ditangkap oleh para pembaca: seorang guru mengajarkan melestarikan lingkungan alam. Didalamnya dipelajari tentang sebab akibat timbul bencana, dan cara penanggulangannya. Misalnya bencana banjir, akibat dari banjir itu sendiri dikarenakan tersumbatnya saluran perairan disungai yang pada akhirnya ketika hujan lebat aliran air sungai meluap ke pedesaan, atau banjir itu sendiri terjadi karena hutan yang gundul, karena hutannya gundul maka daya serap air oleh tanaman berkurang yang akhirnya air mengalir ke pedesaan. Guru tersebut tidak hanya menerangkan sebab dan akibat itu, tidak hanya memberitahu siswa tentang bagaimana cara menanggulanginya, akan tetapi tugas guru disini adalah 
disamping memberi pengetahuan, guru memberikan arahan kepada siswa. Siswa dihadapkan langsung pada pokok permasalahan, dan siswa diberikebebasan untuk menuangkan pengetahuan yang telah dimilikinya sehingga siswa tidak bersifat statis melainkan bergerak dinamis. Sehingga dalam satu pokok pembahasan seorang siswa dalam kelompoknya dapat memperoleh pengetahuan yang berbedabeda sesuai apa yang mereka alami. Dengan kata lain tugas guru dalam Experiential Learning adalah sebagai konselor dan mentor. Konselor jika guru itu berperan mendidik sikap siswa sehingga siswa dapat memiliki pribadi yang bertanggungjawab, sedangkan guru sebagai mentor bagi siswanya adalah memberikan motifasi untuk meraih prestasi.

2. Optimalisasi Experiential Learning dalam Pembelajaran Tematik

Melalui Experiential learning pada jenjang pendidikan dasar yang dalam hal ini menggunakan pembelajaran tematik diharapkan dapat lebih mengoptimalkan proses belajar, selain beberapa hal yang harus diperhatikan dalam model experiental learning, guru juga harus memperhatikan metode belajar melalui pengalaman ini, yaitu meliputi dua hal di bawah ini.

a. Strategi belajar melalui pengalaman berpusat pada siswa dan berorientasi pada aktivitas. Penekanan dalam strategi belajar melalui pengalaman adalah proses belajar, dan bukan hasil belajar.

b. Guru dapat menggunakan strategi ini dengan baik di dalam kelas maupun di luar kelas.

Oleh karena itu, model pembelajaran experiental learning disusun dan dilaksanakan dari hal-hal yang dimiliki oleh peserta didik. Prinsip ini pun berkaitan dengan pengalaman di dalam melaksanakan tugas dan pekerjaan serta dalam cara-cara belajar yang biasa dilakukan oleh peserta didik (Sudjana, 2005). Experiential learning adalah suatu proses belajar mengajar yang mengaktifkan peserta didik untuk membangun pengetahuan dan keterampilan serta nilai-nilai juga sikap melalui pengalamannya secara langsung.

Penerapan Pembelajaran Tematik melalui experiential Learning ini mendorong siswa untuk belajar memecahkan masalah sosial dan saling menghargai. Dalam kehidupan mereka nanti pada saat bermasyarakat di usia dewasanya, siswa-siswa kelas rendah sangat perlu untuk menguasai berbagai keterampilan sosial. Mereka harus mampu dan mempuanyai keterampilan bekerjasama di dalam kelompoknya, melakukan kolaborasi dengan berbagai rekan 
kerja atau siapa saja, belajar berada di dalam kelompok, dan kemampuan memecahkan konflik di antara anggota kelompok yang selanjutnya akan mendorong mereka untuk dapat memecahkan masalah sosial di sekitarnya dengan tetap saling menghargai. Pembelajaran di kelas harus berangkat dari masalah nyata dari kehidupan sehari-hari siswa (real life situation) atau kontekstual. Konsep pembelajaran ini adalah pembelajaran yang sangat bersesuaian dengan prinsip kontekstualitas pembelajaran di kelas ini. Pada model pembelajaran ini, materi pembelajaran yang disampaikan oleh guru seharusnya akan dapat diaplikasikan langsung oleh siswa dalam konteks kehidupannya sehari-hari.

Suasana kelas memungkinkan semua orang yang ada di dalamnya (utamanya siswa dan guru) akan mempunyai perasaan bersedia menanggung resiko bersama-sama. Contohnya saja, semua orang yang ada di dalam kelas akan berusaha menanggapi pertanyaan-pertanyaan yang bahkan berupa pertanyaan yang tidak semestinya atau tidak benar tanpa harus menyinggung perasaan sang penanya. Prosedur-prosedur kerja keseharian, memastikan bahwa semua jadwal dapat diprediksi, dan terdapat jaminan bahwa siswa akan merasa aman saat berada di kelas maupun di luar kelas. Keterampilan hidup yang dipelajari dapat dikenali, didiskusikan dan dipraktikkan oleh siswa dengan interaksi yang tepat dan dengan perasaan senang di dalam komunitasnya di ruang kelas.

\section{E. Kesimpulan}

Agar pembelajaran lebih efektif, efisien dan memiliki daya tarik, sehingga mampu menantang, menyenangkan, mendorong peserta didik untuk bereksplorasi, memberi pengalaman sukses, dan mengembangkan kecakapan berpikir kritis, dilakukan pelatihan dan simulasi menggunakan model Experiential Learning ini.

Kegiatan belajar lebih ditekankan pada aktivitas kontekstual. Maksud dari kegiatan tersebut adalah apa yang dilakukan siswa di kelas merupakan refleksi aktivitas siswa di lingkungan tempat tinggalnya atau di lingkungan sekolahnya. Dengan demikian aktivitas belajar dapat di dilakukan dalam kelas, di luar kelas, atau di lingkungan sekolah. Dalam belajar menekankan siswa aktif bukan berarti ada kebebasan mutlak bagi siswa dalam berkehendak atau bertingkah laku, namun karena adanya keterbatasan pengetahuan yang dimiliki siswa, maka menuntut peran aktif dan kreativitas guru dalam menentukan strategi pembelajaran. Situasi belajar aktif tersebut 
tercipta jika guru memfasilitasi dan memberi kesempatan kepada siswa untuk berbuat atau belajar, Peran Guru sebagai organisator, fasilitator, dan motivator.

Pembelajaran tematik berbasis Experiential Learning sebagai suatu konsep merupakan pendekatan pembelajaran yang melibatkan beberapa mata pelajaran untuk memberikan pengalaman belajar yang bermakna bagi anak. Pembelajaran tematik diyakini sebagai pendekatan yang berorientasi pada praktik pembelajaran yang sesuai dengan kebutuhan anak. Pembelajaran tematik secara efektif akan membantu menciptakan kesempatan yang luas bagi siswa untuk melihat dan membangun konsep-konsep yang saling berkaitan. Dengan demikian, pembelajaran akan memberikan kesempatan kepada siswa untuk memahami masalah yang kompleks yang ada di lingkungan sekitarnya dengan pandangan yang utuh. Dengan pembelajaran tematik ini siswa diharapkan memiliki kemampuan untuk mengidentifikasi, mengumpulkan, menilai dan menggunakan informasi yang adadi sekitarnya secara bermakna. Hal itu dapat diperoleh tidak saja melalui pemberian pengetahuan baru kepada siswa melainkan juga melalui kesempatan memantapkan dan menerapkannya dalam berbagai situasi baru yang semakin beragam. Dengan demikian, keterpaduan dalam pembelajaran tematik ini dapat dilihat dari aspek proses, aspek kurikulum, dan aspek belajar mengajar.

Kegiatan pembelajaran yang menekankan proses diharapkan dapat memberi pengalaman konkret bagi siswa, dengan demikian pembelajaran menjadi bermakna dan berkualitas. Pembelajaran dikatakan berkualitas jika guru menyajikan permasalahan yang menantang menyenangkan, memberi kesempatan kepada siswa untuk bereksplorasi, memberi pengalaman sukses, mengembangkan kecakapan berpikir dan dalam pembelajarannya memanfaatkan sumber belajar baik berupa sumber belajar alami maupun hasil desain. 


\section{DAFTAR PUSTAKA}

Amir Achsin. 1984. Belajar Melalui Pengalaman (Experiential Learning). Jakarta: Direktorat Jendral Pendidikan, Proyek Pengembangan Lembaga Pendidikan Tenaga Kependidikan.

Amirul Hadi \& Daryono.1998. Metodologi Penelitian Pendidikan, Bandung : Pustaka Setia.

Anita Lie. 2004. Cooperatif Learning. Jakarta: Grasindo.

Asri Budiningsih. C. 2002. Belajar dan Pembelajaran. Yogyakarta: Fakultas Ilmu Pendidikan Universitas Negeri Yogyakarta.

Baharuddin, dkk. 2007. Teori Belajar \& Pembelajaran, Yogyakarta: Ar-Ruzz Media.

David A. Kolb. 1984. Experiential Learning as a Source of Development, Prentice Hall. New Jersey.

Dudung Abdurrahman. 2000. Pengantar Metode Penelitian, Yogyakarta : Galang Press.

Hamzah B. Uno. 2006. Orientasi Baru dalam Psikologi Pembelajaran, Jakarta: Bumi Aksara.

Husaini Usman \& Purnomo Setiady. 1996. Metodologi Penelitian Sosial, Jakarta : Bumi Aksara.

Isah Cahyani. 2002. Peran Experiential Learning dalam Meningkatkan Motivasi Pembelajar $B I P A$. Bandung.

Lexy J. Moleong. 2002. Metodologi Penelitian Kualitatif, Bandung : Rosda Karya.

Mel. Silberman. 2001. Active Learning; 101 Strategi Pembelajaran Aktif, terj. Sardjuli dkk., Yogyakarta: YAPPENDIS.

Noeng Muhadjir. 1998. Metode Penelitian Kualitatif, Yogyakarta : Rake Sarasin.

P. Joko Subagyo. 1991. Metodologi Penelitian dan Praktek, Jakarta : Rineka Cipta.

Ronny Kountur. 2004. Metode Penelitian untuk Penulisan Skripsi dan Tesis. Jakarta : PPM.

Sugiyanto. 2007. Modul Pendidikan dan Latihan Profesi Guru (PLPG). Model-model Pembelajaran Inovatif. Panitia Sertifikasi Guru Rayon 13. Surakarta.

Suharsimi Arikunto.1998. Metodologi Penelitian Suatu Pendekatan Praktek, Jakarta : Rineka Cipta. 